\title{
Effect of tendu (Diospyros melanoxylon RoxB.) leaf vermicompost on growth and yield of French bean (Phaseolus vulgaris $\mathbf{L}$.)
}

\author{
Dilip Kadam • Girish Pathade
}

Received: 11 April 2013/Accepted: 25 December 2013/Published online: 21 February 2014

(C) The Author(s) 2014. This article is published with open access at Springerlink.com

\begin{abstract}
Background Tendu (Diospyros melanoxylon RoxB.) leaf is widely used in India in the form of wrapper for making a crude smoking stick popularly known as "Beedi". Solapur city of Maharashtra state has large number of small beedi making units. Large quantity waste from these industries in the form of trimmed leaf residues is available as feed material for preparation of vermicompost. The present investigations were aimed to study effect of vermicompost prepared from such novel leaf residues as the tendu leaves on the growth and yield of Phaseolus vulgaris under greenhouse conditions. The seeds of French bean were sown in cement pots containing soil alone (control), soil with various concentrations of vermicompost alone, soil with various concentrations of urea only and different admixtures of vermicompost and urea.

Results The study revealed that the seed germination, shoot and root length, shoot and root fresh weights, shoot and root dry weights, thousand grain weight and grain weight per plant increased significantly $(p \leq 0.05)$ compared to control due to application of vermicompost when used at proper proportions. Thus, the growth and yield parameters were significantly $(p \leq 0.05)$ greater in $\mathrm{T}_{2}$ $\left(75 \% \mathrm{~N}\right.$ through vermicompost) than in $\mathrm{T}_{1}(100 \% \mathrm{~N}$ through vermicompost) and $\mathrm{T}_{3}(50 \% \mathrm{~N}$ through vermicompost). Many growth parameters of $\mathrm{T}_{1}$ were lower than
\end{abstract}

\footnotetext{
D. Kadam ( $($ )

Department of Microbiology, D.B.F.Dayanand College of Arts and Science, Solapur 413002, Maharashtra, India

e-mail: kadamdgin@ rediffmail.com

G. Pathade

Department of Biotechnology, Fergusson College, Pune, Maharashtra, India

e-mail: girishpathade@yahoo.co.in
}

those in the control indicating some deleterious effect of vermicompost at higher concentrations. The combined application of tendu leaf vermicompost and urea increased the growth and yield of Phaseolus vulgaris significantly $(p \leq 0.05)$. The maximum grain yield was due to combined application of vermicompost at $25 \% \mathrm{~N}$ through vermicompost plus $75 \% \mathrm{~N}$ through urea.

Conclusions The pot trial experiments suggested that the quantity of chemical fertilizer for French bean could be reduced by $25-50 \%$ due to combined application of vermicompost and chemical fertilizer. However, application of tendu leaf vermicompost alone at higher concentrations may reduce growth parameters and yield of $P$. vulgaris.

Keywords Tendu leaf vermicompost $\cdot$ Urea $\cdot$ Growth and yield P Phaseolus vulgaris

\section{Introduction}

Vermicomposting is a process of composting organic waste material of diverse origin such as domestic, agricultural and industrial through the agency of suitable kind of earthworm species. The worms feed on organic materials, and fragment and digest them in their gut by their own enzymes and with the help of ingested micro-organisms, and excrete nutritionally rich feces or casts. During this process, the nutritional elements in the organic matter are mineralized and concentrated into soluble and readily available forms through microbial action (Edwards 1995). The earthworm casts have been shown to contain increased quantities of important plant nutritional elements such as nitrogen, phosphorus and potassium together with the biologically active substances stimulating plant growth (Lee 1985). 
Several studies have examined growth of plants using vermicompost derived from different materials in green house conditions or in field studies (Atiyeh et al. 2000). All such studies indicated beneficial effects of vermicompost on plant growth. Recently, Manivannan et al. (2009) observed favorable effects of vermicompost on the growth and yield of beans and recommended the use of ptb (press mud, sugar cane thrash and fine bagasse) vermicompost alone or in combination with chemical fertilizer for improved productivity. Sutar (2009) reported increased growth and yield of Allium sativum L. (garlic) due to application of vermicompost. Chanda et al. (2011) studied the effect of vermicompost and other fertilizers on the growth of tomato plants and reported significant increase in growth parameters of the plants treated with vermicompost supplemented with chemical fertilizers. Cristina et al. (2010) studied influence of vermicompost on pine (Pinus pinaster Ait.) and reported significant inhibition of aerial and root biomass with high dose of solid vermicompost. Thus, despite large body of scientific evidence showing beneficial effect of plant growth and yield; there is also strong evidence that these effects are not general or constant (Cristina and Jorge 2011).

Therefore, present investigations were aimed to study effect of vermicompost prepared from such novel leaf residues as the tendu leaves to observe its effect on plant growth and yield. The objective of present study was to assess growth and yield of Phaseolus vulgaris when grown in soil (control) and soil with vermicompost alone, soil with urea alone, soil with admixtures of vermicompost and urea under green house conditions.

\section{Methods}

Tendu leaf vermicompost

The vermicompost was prepared by inoculating $1 \mathrm{~kg}$ shredded and precomposted tendu leaf residues with 20 adult Eudrilus eugeniae worms and incubating the pot at $25^{\circ} \mathrm{C}$ temperature for 10 days. The moisture content of the pot was adjusted between 60 and $70 \%$ by sprinkling distilled water. After incubation the vermicomposted material was collected, sieved and stored for further use. The physico-chemical properties of tendu leaf vermicompost were determined by methods described in Trivedi and Goel (1984) and are summarized in Table 1.

Pot trial studies

Cement pots of 10-kg capacity were filled with clay loam soil from the campus of Regional Agriculture Center, Solapur. The soil was wetted with distilled water to $50 \%$ of water holding capacity and incubated for $48 \mathrm{~h}$ before sowing. The pots were added separately with vermicompost, chemical fertilizer (urea) and admixtures of both as per pattern given in Table 2.

Twenty seeds were sowed per pot at $0.5 \mathrm{~cm}$ depth and incubated under green house conditions. The germination percentage was measured 1 week after the emergence of seedlings. Plants were harvested at 60 and 120 days to measure growth and yield, respectively. The shoots and roots were dried at $60{ }^{\circ} \mathrm{C}$ for dry weight determination.

Statistical analysis

The experimental data was expressed as mean $\pm \mathrm{SE}$ and Student's $t$ test was carried out to determine significant differences of different parameters in different treatments from the control at $p \leq 0.05$ level.

\section{Results and discussion}

\section{Seed germination}

The seed germination percentage of French bean in control soil $\left(\mathrm{T}_{10}\right)$ was $83.3 \pm 1.77 \%$, which was increased to $96.6 \pm 3.3$ in $75 \%$ vermicompost treatments $\left(\mathrm{T}_{2}\right)$. The germination percentage in $\mathrm{T}_{1}\left(100 \%\right.$ vermicompost) and $\mathrm{T}_{3}$ (50\% vermicompost), however, was 90 and $86.6 \pm 3.3 \%$, respectively. The maximum germination percentage $(100 \%)$ was observed in $\mathrm{T}_{7}(75 \%$ urea $+25 \%$ vermicompost) and $\mathrm{T}_{8}(25 \%$ urea $+75 \%$ vermicompost) treatments. The minimum seed germination percentage $(83.3 \%)$ was found in $\mathrm{T}_{6}, \mathrm{~T}_{9}$ and $\mathrm{T}_{10}$ (control soil) treatments (Fig. 1).

Plants' shoot and root length

The maximum shoot length was observed in $\mathrm{T}_{2}$ showing $36 \%$ increase over the control $\left(\mathrm{T}_{10}\right)$. Among the treatments receiving vermicompost alone, $\mathrm{T}_{1}(100 \%$ vermicompost) showed $6.56 \%$ decrease in shoot length while $\mathrm{T}_{3}$ (50\% vermicompost) showed only $10 \%$ increase over that of control. Among the treatments that received urea (chemical fertilizer) alone, $\mathrm{T}_{4}(100 \% \mathrm{U})$ showed maximum $(30 \%)$ increase in shoot length over control while $\mathrm{T}_{5}$ $(75 \% \mathrm{U})$ and $\mathrm{T}_{6}(50 \% \mathrm{U})$ showed 13 and $16.5 \%$ increase in shoot length, respectively. Among the admixture treatments $\mathrm{T}_{7}(22.8 \%), \mathrm{T}_{8}(20.6 \%)$ and $\mathrm{T}_{9}(17.1 \%)$ showed significant $(p \leq 0.05)$ increase over the control (Fig. 2).

The maximum root length was observed in $\mathrm{T}_{7}$ showing $65 \%$ increase over the control followed by $\mathrm{T}_{2}$ and $\mathrm{T}_{3}$ treatment showing 58 and $54.3 \%$ increase, respectively, over the control. $\mathrm{T}_{1}$ treatment showed significantly $(p \leq 0.05)$ lower root length increase $(11.4 \%)$ over the 
Table 1 Physicochemical characteristics of raw and partially decomposed tendu leaf residues and tendu leaf vermicompost (mean $\pm \mathrm{SE})$

$B D L$ below detectable level

\begin{tabular}{llll}
\hline Parameter & $\begin{array}{l}\text { Raw tendu } \\
\text { leaf residues }\end{array}$ & $\begin{array}{l}\text { Partially decomposed } \\
\text { tendu leaf residues }\end{array}$ & $\begin{array}{l}\text { Tendu leaf } \\
\text { vermicompost }\end{array}$ \\
\hline PH & $8.2 \pm 0.1$ & $7.2 \pm 0.2$ & $7.40 \pm 0.2$ \\
Carbon (\%) & $58.0 \pm 2.07$ & $38 \pm 1.78$ & $29.0 \pm 1.0$ \\
Nitrogen (\%) & $1.38 \pm 0.01$ & $1.29 \pm 0.19$ & $1.43 \pm 0.06$ \\
Phosphorus (\%) & $0.084 \pm 0.03$ & $0.043 \pm 05$ & $0.29 \pm 0.01$ \\
Potassium (\%) & $0.43 \pm 0.01$ & $0.29 \pm 0.01$ & $0.23 \pm 0.01$ \\
Calcium (\%) & $1.20 \pm 0.02$ & $1.54 \pm 0.051$ & $2.60 \pm 0.01$ \\
Magnesium (\%) & $5.34 \pm 0.03$ & $1.262 \pm 0.1$ & $2.33 \pm 0.01$ \\
Iron (ppm) & $35.0 \pm 1.52$ & $290.0 \pm 3.6$ & $270.0 \pm 3.6$ \\
Copper (ppm) & $30.0 \pm 1.0$ & $12.0 \pm 0.50$ & $24.0 \pm 1.0$ \\
Manganese (ppm) & $\mathrm{BDL}$ & $10.0 \pm 0.01$ & $10.0 \pm 0.02$ \\
Zinc (ppm) & $14 \pm 1.52$ & $18.0 \pm 2.51$ & $20.0 \pm 1.0$ \\
C/N ratio & 42 & 29.45 & 20.27 \\
\hline
\end{tabular}

Table 2 Admixture pattern of vermicompost and urea in pot trials

\begin{tabular}{|c|c|c|c|c|c|c|}
\hline \multirow[t]{2}{*}{ Sr. no. } & \multirow[t]{2}{*}{ Treatment } & \multirow[t]{2}{*}{ Treatment details } & \multirow{2}{*}{$\begin{array}{l}\text { Soil in } \\
\text { each pot }(\mathrm{kg})\end{array}$} & \multicolumn{3}{|l|}{ Fertilizer used (g/pot) } \\
\hline & & & & Vermicompost & Urea & $\begin{array}{l}\text { Admixture of urea } \\
\text { and vermicompost }\end{array}$ \\
\hline 1 & $\mathrm{~T}_{1}$ & $100 \% \mathrm{~N}$ by $\mathrm{V}$ & 10 & $46.86^{\mathrm{a}}($ for $100 \% \mathrm{~N})$ & - & - \\
\hline 2 & $\mathrm{~T}_{2}$ & $75 \% \mathrm{~N}$ by $\mathrm{V}$ & 10 & $35.15($ for $75 \% \mathrm{~N})$ & - & - \\
\hline 3 & $\mathrm{~T}_{3}$ & $50 \% \mathrm{~N}$ by $\mathrm{V}$ & 10 & $23.43($ for $50 \% \mathrm{~N})$ & - & - \\
\hline 4 & $\mathrm{~T}_{4}$ & $100 \% \mathrm{~N}$ by $\mathrm{U}$ & 10 & - & $1.455($ for $100 \% \mathrm{~N})$ & - \\
\hline 5 & $\mathrm{~T}_{5}$ & $75 \% \mathrm{~N}$ by $\mathrm{U}$ & 10 & - & $1.09($ for $75 \% \mathrm{~N})$ & - \\
\hline 6 & $\mathrm{~T}_{6}$ & $50 \% \mathrm{~N}$ by $\mathrm{U}$ & 10 & - & 0.727 (for $50 \% \mathrm{~N}$ ) & - \\
\hline 7 & $\mathrm{~T}_{7}$ & $75 \% \mathrm{~N}$ by $\mathrm{U}+25 \% \mathrm{~N}$ by $\mathrm{V}$ & 10 & - & - & $\begin{array}{l}1.092(75 \% \mathrm{~N}) \mathrm{U} \\
\quad+11.715(25 \%) \mathrm{V}\end{array}$ \\
\hline 8 & $\mathrm{~T}_{8}$ & $25 \% \mathrm{~N}$ by $\mathrm{U}+75 \% \mathrm{~N}$ by $\mathrm{V}$ & 10 & - & - & $\begin{array}{l}0.363(25 \% \mathrm{~N}) \mathrm{U} \\
\quad+35.15(75 \% \mathrm{~N}) \mathrm{V}\end{array}$ \\
\hline 9 & $\mathrm{~T}_{9}$ & $50 \% \mathrm{~N}$ by $\mathrm{U}+50 \% \mathrm{~N}$ by $\mathrm{V}$ & 10 & - & - & $\begin{array}{l}0.727(50 \% \mathrm{~N}) \mathrm{U} \\
\quad+23.43(50 \% \mathrm{~N}) \mathrm{V}\end{array}$ \\
\hline 10 & $\mathrm{~T}_{10}$ control & Only soil & 10 & - & - & - \\
\hline
\end{tabular}

$U$ urea, $V$ vermicompost

${ }^{\text {a }}$ Recommended dose of nitrogen to the soil is an average $50 \mathrm{~kg} / \mathrm{hector}$

control indicating some deleterious effect at $100 \%$ vermicompost. The increases in root length in all the treatments receiving urea only were significantly $(p \leq 0.05)$ lower than the vermicompost treatments. Thus there were only $28 \%\left(\mathrm{~T}_{4}\right), 8.7 \%\left(\mathrm{~T}_{5}\right)$ and $0.9 \%\left(\mathrm{~T}_{6}\right)$ increase in root length over the control. $\mathrm{T}_{9}$ treatment $(5.2 \%)$ also showed decreased root length similar to $\mathrm{T}_{1}$ (Fig. 2).

Plants' shoot and root fresh weights

The maximum shoot weight increase was in $\mathrm{T}_{4}(83 \%)$ followed by $\mathrm{T}_{2}(72.3 \%)$. The shoot weight in $\mathrm{T}_{1}$, however, decreased $(-9.4 \%)$ significantly $(p \leq 0.05)$ compared to control. All the treatments receiving urea alone viz. $\mathrm{T}_{4}$
(83\%), $\mathrm{T}_{5}(56.8 \%)$ and $\mathrm{T}_{6}(51.5 \%)$ showed significant $(p \leq 0.05)$ increase in shoot fresh weights. Among the admixture treatments maximum increase $(38.5 \%)$ in shoot weights was in $\mathrm{T}_{7}$ followed by $\mathrm{T}_{9}(29.2 \%)$ and $\mathrm{T}_{8}$ $(18.5 \%)$ treatments. The maximum increase $(36.6 \%)$ in root fresh weight was observed in $\mathrm{T}_{4}$ treatment followed by $\mathrm{T}_{2}(30.25 \%)$. The root fresh weights in $\mathrm{T}_{1}$ decreased $(-1.6 \%)$ significantly $(p \leq 0.05)$ compared to those in control. The increase in root fresh weights in $\mathrm{T}_{3}(50 \% \mathrm{~V})$ and $\mathrm{T}_{5}(75 \% \mathrm{U})$ was similar $(8.25 \%)$. Among the admixture treatments significant $(p \leq 0.05)$ increase $(19.82 \%)$ in root fresh weights was observed only in $\mathrm{T}_{9}$ while $\mathrm{T}_{7}$ and $\mathrm{T}_{8}$ showed significantly $(p \leq 0.05)$ decreased root fresh weights compared to the control (Fig. 3). 
Fig. 1 The germination percentage of French bean ( $P$. vulgaris) seeds in various treatments of tendu leaf vermicompost and chemical fertilizer (mean $\pm \mathrm{SE}$ ). Data analyzed by Student's $t$ test at $p \leq 0.05$ to calculate significant differences of treatments from the control $\left(\mathrm{T}_{10}\right)$
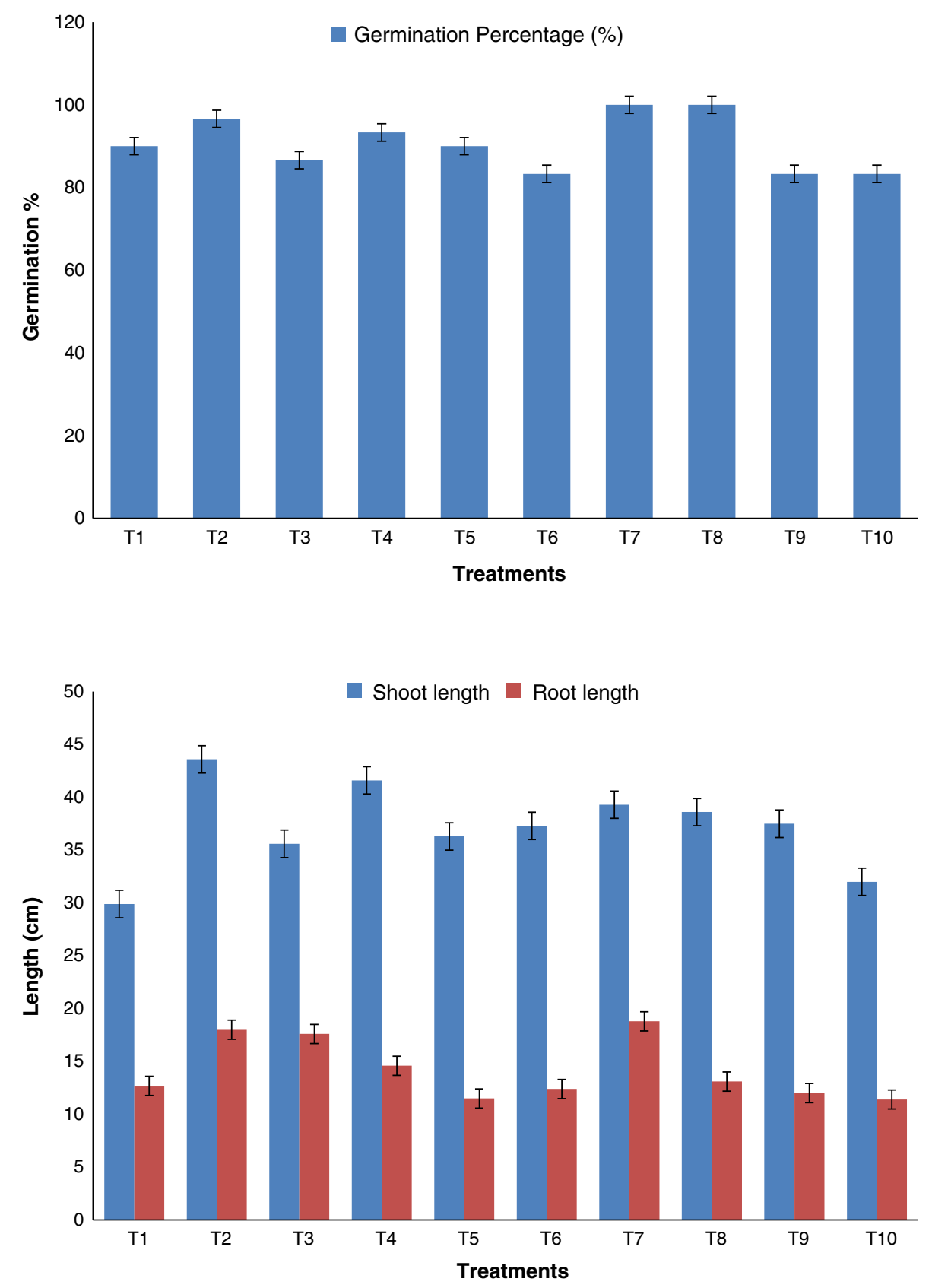

Fig. 2 The effect of tendu leaf vermicompost and chemical fertilizer on shoot and root length of French bean (mean \pm SE). Data analyzed by Student's $t$ test at $p \leq 0.05$ to calculate significant differences of treatments from the control $\left(\mathrm{T}_{10}\right) . F W$ fresh weight, $D W$ dry weight
Plant shoot and root dry weights

Among the treatments that received vermicompost alone, the maximum increase $(46.8 \%)$ in shoot dry weights was observed in $\mathrm{T}_{2}$ whereas shoot dry weight in $\mathrm{T}_{1}$ was lower $(-23.4 \%)$ compared to control and only $6 \%$ increase over the control was observed in $\mathrm{T}_{3}$. Among the treatments that received urea alone, the maximum increase $(56 \%)$ in shoot dry weight was observed in $\mathrm{T}_{4}$ followed by $\mathrm{T}_{5}(50.4 \%)$ and $\mathrm{T}_{6}(43.5 \%)$ over the control.

The maximum increase in root dry weights was observed in $\mathrm{T}_{4}(41.6 \%)$, whereas the increase in root dry weights in $\mathrm{T}_{2}(25 \%)$ and $\mathrm{T}_{9}(25.83 \%)$ was similar. Except $\mathrm{T}_{3}$ and $\mathrm{T}_{5}$, rest of all treatments showed reduced root dry weights as compared to control (Fig. 3).

Thousand grain weight

Among the treatments that received vermicompost alone, maximum weight of thousand grains (374.0 g) was observed in $\mathrm{T}_{2}$ with $20.3 \%$ increase over that of control (311.0 g). Among the treatments with chemical fertilizer alone, the maximum weight of thousand grains (398.0) was found in $\mathrm{T}_{4}$ with $28 \%$ increase over that of control. The 
thousand grain weight in $\mathrm{T}_{6}(379.0 \mathrm{~g})$ and $\mathrm{T}_{9}(378.0 \mathrm{~g})$ did not differ significantly $(p \leq 0.05)$ whereas $\mathrm{T}_{7}(394.5 \mathrm{~g})$ and $\mathrm{T}_{8}(392.2 \mathrm{~g})$ also showed similar increase $(26 \%)$ in thousand grain weight over the control (Fig. 4).

\section{Grain weight per plant and grain yield}

The maximum increase in grain weight per plant was observed in $\mathrm{T}_{7}(46.9 \%)$ and $\mathrm{T}_{4}(46.6 \%)$ compared to that in the control. The grain weight per plant in $\mathrm{T}_{7}, \mathrm{~T}_{8}$ and $\mathrm{T}_{9}$ did not differ significantly. Among the treatments that received vermicompost alone, $\mathrm{T}_{2}$ showed $80.52 \mathrm{~g}$ grain weight per plant with $32 \%$ increase over the control. The interaction effects of vermicompost and chemical fertilizers were significant. The maximum increase in grain yield was in $\mathrm{T}_{4}(53.16 \%)$ followed by $\mathrm{T}_{7}(51.5 \%)$ and $\mathrm{T}_{9}$ $(40.28 \%)$. Among the vermicompost alone treatments, maximum increase in the yield was $37.5 \%$ in $\mathrm{T}_{2}$. These results indicate that the interaction effect of vermicompost and chemical fertilizer was significant (Fig. 4).

The data on various growth and yield parameters of French bean such as germination percentage, shoot and root length, shoot and root fresh as well as dry weights, grain weight per plant, thousand grain weights etc. revealed that they were significantly $(p \leq 0.05)$ higher in vermicompost treatments compared to control treatments. The significant increase in the yield of French bean due to application of tendu leaf vermicompost might be due to increased content of available nutrients in the vermicompost, increased number of beneficial kinds of micro-
Fig. 3 The effect of tendu leaf vermicompost and chemical fertilizer on shoot and root fresh weights and shoot and root dry weights of French bean (mean $\pm \mathrm{SE}$ ). Data analyzed by Student's $t$ test at $p \leq 0.05$ to calculate significant differences of treatments from the control $\left(\mathrm{T}_{10}\right)$

Fig. 4 The effect of tendu leaf vermicompost and chemical fertilizer on grain weights and grain yield of French bean (mean \pm SE). Data analyzed by Student's $t$ test at $p \leq 0.05$ to calculate significant differences of treatments from the control $\left(\mathrm{T}_{10}\right)$
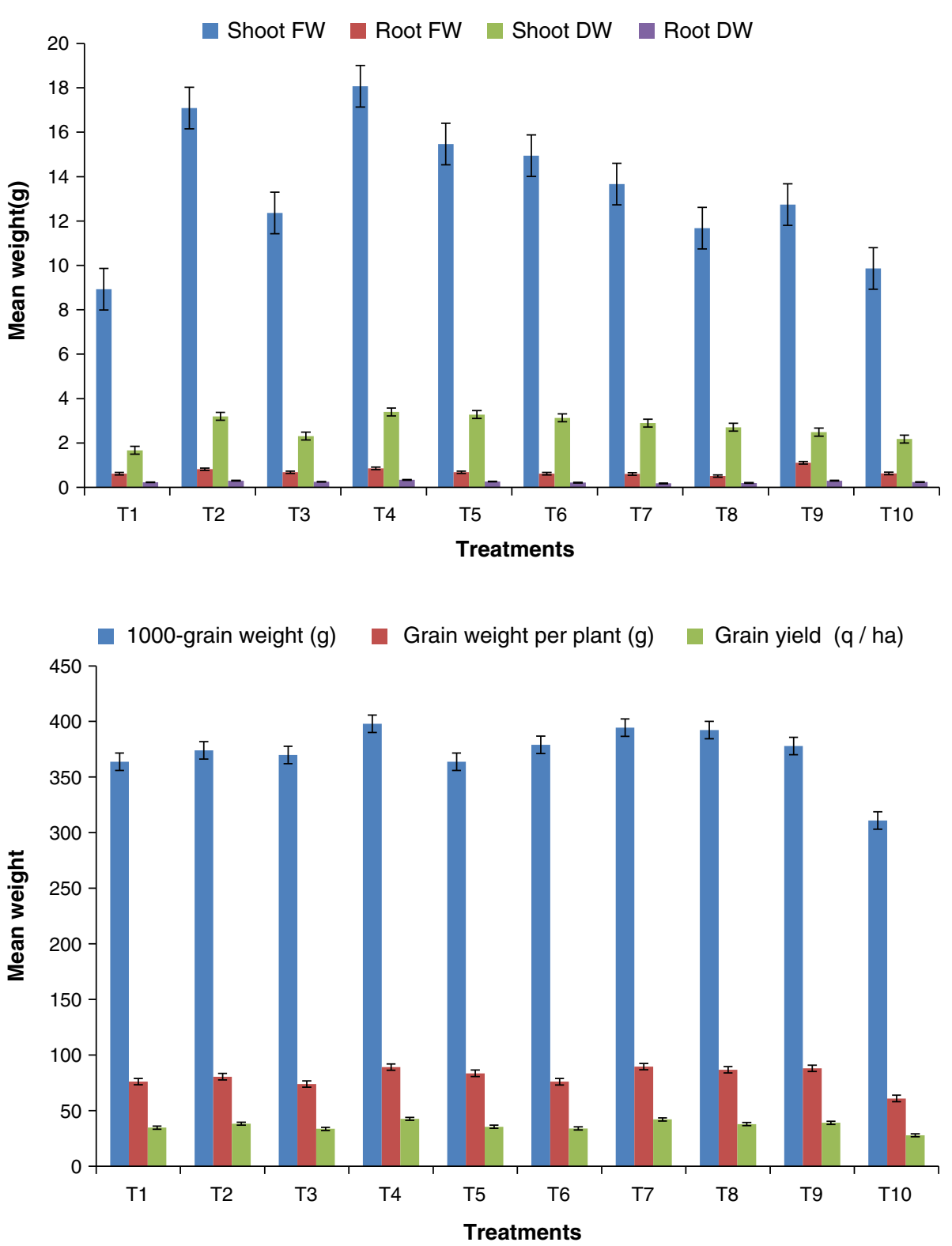
organisms, increased enzyme activities as well as presence of plant growth stimulating substances like gibberellins, cytokinins, auxins etc. in the vermicompost. The presence of biologically active substances in the vermicompost might have increased the availability of nutrients in soil and their uptake by the plant due to improved root system.

It is well-known that vermicompost is rich in essential nutritional elements for plant growth, beneficial microorganisms, plant growth promoting substances and different types of enzymes and as such the vermicompost can be applied alone or in combination with other organic or inorganic fertilizers to obtain better yields of different crops (Bano et al. 1987).

There are several other reports on favorable effect of vermicomposts on various plants (Kale et al. 1987; Vadiraj et al. 1992). Atiyeh et al. (2000) reported that the shoot dry weights of raspberry plant soil mixed with vermicomposted pig wastes weighted more than those grown in unfertilized control soil, and were as great as those in soil receiving a chemical fertilizer treatment.

However, an important observation made by us during our investigations is that the application of tendu leaf vermicompost at a level of $100 \% \mathrm{~N}$ through vermicompost resulted in significantly $(p \leq 0.05)$ decreased growth parameters as compared to the treatments that received tendu leaf vermicompost at a level of 75 or $50 \% \mathrm{~N}$ through vermicompost alone. This is indicative of some detrimental effect of tendu leaf vermicompost application above certain threshold concentrations on the growth of French bean plant. These observations corroborate with the reports of Cristina et al. (2010) who stated that substitution of peat with higher dose vermicompost resulted in detrimental effect on Pine seedling growth, and beneficial effects were observed only at lower doses of vermicompost in potting media.

The data showed that combined application of various levels of chemical fertilizer (urea) with tendu leaf vermicompost resulted in significant $(p \leq 0.05)$ increase in growth and yield of French bean compared to control. The maximum grain yield of French bean (42.12 q/ha) was recorded in $\mathrm{T}_{7}$ treatment that received combined application of $25 \% \mathrm{~N}$ through vermicompost plus $75 \% \mathrm{~N}$ through urea followed by $\mathrm{T}_{9}$ treatment that received combined application of $50 \% \mathrm{~N}$ through urea plus $50 \% \mathrm{~N}$ through vermicompost. These results suggest that the quantity of chemical fertilizers for French bean could be reduced by $25-50 \%$ due to combined application of vermicompost with chemical fertilizer. These results are comparable with those reported by Kale (1998) who suggested that the quantity of chemical fertilizers could be reduced to $25-50 \%$ due to application of vermicompost for plants like brinjal, tomato, radish and carrot.

The combined application of tendu leaf vermicompost and chemical fertilizer (urea) increased the growth and yield of French bean (P. vulgaris) significantly $(p \leq 0.05)$. The maximum grain yield of French bean was obtained due to combined application of tendu leaf vermicompost at $25 \% \mathrm{~N}$ through vermicompost plus $75 \% \mathrm{~N}$ through urea followed by combined application of $50 \% \mathrm{~N}$ through urea plus $50 \% \mathrm{~N}$ through vermicompost. The increase in the yield due to above treatments accounted for almost similar yields as that of $100 \%$ recommended dose of NPK fertilizers and $23.8 \%$ increased yields over $75 \%$ recommended dose of NPK fertilizers and $29.5 \%$ increased yields over the $50 \%$ recommended dose of NPK fertilizers.

Most of the growth and yield parameters in of French bean (Figs. 1, 2, 3 and 4) in $\mathrm{T}_{4}(100 \% \mathrm{~N}$ through urea) do not differ significantly $(p \leq 0.05)$ from $\mathrm{T}_{7}(25 \% \mathrm{~N}$ through vermicompost plus $75 \% \mathrm{~N}$ through urea) and $\mathrm{T}_{9}$ (50\% $\mathrm{N}$ through vermicompost plus $50 \% \mathrm{~N}$ through urea) though the chemical fertilizer quantity is reduced to 25-50\% compared to $\mathrm{T}_{4}$. This might be due to the contribution made by the quantity and quality of vermicompost in increasing growth and yield of the plant in these treatments. Similarly most of growth and yield parameters in $\mathrm{T}_{2}$ ( $75 \% \mathrm{~N}$ through vermicompost) and $\mathrm{T}_{8}(25 \% \mathrm{~N}$ through urea plus $75 \% \mathrm{~N}$ through vermicompost) do not differ significantly $(p \leq 0.05)$ indicating the potential of vermicompost to contribute nitrogen and other plant growth promoting substances that can compensate decreased levels of chemical fertilizer. Moreover, growth and yield parameters in all treatments except $\mathrm{T}_{1}$ differ significantly $(p \leq 0.05)$ than the control soil $\left(\mathrm{T}_{1}\right)$.

\section{Conclusion}

The pot trial experiments suggest that the quantity of chemical fertilizers for French bean plants could be reduced by $25-50 \%$ due to combined application of tendu leaf vermicompost with chemical fertilizer. Moreover, application of tendu leaf vermicompost alone at higher concentrations (100\% $\mathrm{N}$ through vermicompost) may reduce certain growth parameters and yield of $P$. vulgaris plants.

Open Access This article is distributed under the terms of the Creative Commons Attribution License which permits any use, distribution, and reproduction in any medium, provided the original author(s) and the source are credited.

\section{References}

Atiyeh RM, Subler S, Edwards CA, Buchman G, Metzer JD, Shuster W (2000) Effects of vermicomposts and composts on plant 
growth in horticultural container media and soil. Pedobiologia 44(5):579-590

Bano K, Kale RD, Gajanan GN (1987) Culturing of earthworm Eudrilus eugeniae for cast production and assessment of worm cast as biofertilizer. J Soil Biol Ecol 7:98-104

Chanda GK, Goutam B, Chakraborty SK (2011) The effect of vermicompost and other fertilizers on cultivation of Tomato plants. J Hortic For 3(2):42-45

Cristina L, Jorge D (2011) The use of vermicompost in sustainable agriculture: impact on plant growth and soil fertility. In: Miransari $M$ (ed) Soil nutrients, chapter 10. Nova Science Publishers Inc, New York

Cristina L, Luis S, Rafael Z, Jorge D (2010) Assessment of plant growth promotion by vermicompost in different progenies of Maritime Pine (Pinus pinaster Ait.). Compost Sci Util 18(2):111-118

Edwards CA (1995) Historical overview of vermicomposting. Biocycle 36:56-58

Kale RD, Bano K, Sreenivas MN, Bhagyaraj DJ (1987) Influence of worm cast on the growth and mycorrhizal colonization of two ornamental plants. South Indian Hortic 35:433-437
Kale RD (1998) Earthworm Cinderella of Organic Farming. Chapter 3. Prism Books Pvt. Ltd., Bangalore

Lee KE (1985) Earthworms, their ecology and relationships with soils and land use. Academic Press, Sydney

Manivannan S, Balamurugan M, Parthsarathi K, Gunasekaran G, Ranganathan LS (2009) Effect of vermicompost on soil fertility and crop productivity- ${ }^{\circ}$ beans (Phaseolus vulgaris). J Environ Biol 30(20):275-281

Sutar S (2009) Impact of vermicompost and composted farmyard manure on growth and yield of garlic (Allium sativum L.) field crop. Int J Plant Prot 3(1):27-38

Trivedi RK, Goel PK (1984) Chemical and biological methods for water pollution studies. Environmental Publications, Karad

Vadiraj BA, Krishnakumar M, Jayakumaran NR (1992) Studies on vermicompost and the effect on cardamom nursery seedlings. Proc Natl Sym Soil Biol Ecol 53-57 